\title{
OKOLJSKA IN RAZVOJNA VLOGA KMETIJSTVA V MESTNI OBČINI LJUBLJANA
}

\author{
Barbara Lampič \\ Oddelek za geografijo Filozofske fakultete Univerze v Ljubljani \\ Aškerčeva cesta 2, SI - 1000 Ljubljana, Slovenija \\ e-mail: barbara.lampic@ff.uni-lj.si
}

Izvirni znanstveni članek

COBISS 1.01

\section{Izvleček}

$\mathrm{V}$ prispevku so predstavljeni rezultati raziskave vrednotenja kmetijstva in njegove okoljske vloge s poudarkom na obsegu in vrstah kmetijskega obremenjevanja ter perspektivi kmetijstva na širšem območju Ljubljane. Pokrajinska heterogenost občine pomembno vpliva na usmeritev in funkcije kmetijstva, sedanjo in bodočo rabo zemljišč. Število aktivnih kmetij se je v zadnjem desetletju pomembno zmanjšalo, njihovo upadanje pa se postopoma umirja. Od trenutno 600 aktivnih kmetij je pričakovati, da se bo njihovo število znižalo še za 20 do $30 \%$, spremenila pa se bo njihova struktura in velikost.

Ključne besede: Kmetijstvo, naravni viri, raba tal, značilnosti kmetijstva in kmetij, energetski vnosi, kmetijsko obremenjevanje, prihodnost kmetijstva, Mestna občina Ljubljana.

\section{THE ENVIRONMENTAL AND DEVELOPMENTAL ROLE OF AGRICULTURE IN MUNICIPALITY OF LJUBLJANA}

\begin{abstract}
The article deals with the results of a survey concerning the evaluation of agriculture and its environmental role. Special emphasis is placed on the extent and types of agriculture burdening, as well as perspectives in agriculture in the greater Ljubljana area. The diversity of landscape in municipality has significant influence on the orientation and functions of agriculture, and on the present and future land use. Over the last decade, there has been a significant decline in the number of active farms, although the trend is gradually slowing down. It is anticipated that the number of the currently 600 active farms will decrease by a further $20-30 \%$, and their structure and size will also change.
\end{abstract}

Key words: Agriculture, natural resources, land use, agriculture and farms characteristics, energy inputs, agriculture burdening, perspectives in agriculture, Municipality of Ljubljana. 


\section{UVOD}

Širše območje Mestne občine Ljubljana (MOL) predstavlja središče in gonilo gospodarskega in družbenega razvoja Slovenije, kmetijstvo pa ima na tem območju specifično vlogo. Zaradi osrednje gospodarske vloge tega območja se je kmetijstvo na eni strani znašlo v primežu, ujeto med številne bolj agresivne (in gospodarsko prednostne) dejavnosti, po drugi strani pa so prav na tem območju naravne možnosti za kmetovanje razmeroma ugodne, predvsem pa je bližina največjega trga $\mathrm{v}$ državi izjemna razvojna priložnost za trženje kmetijskih pridelkov in proizvodov.

Položaj, vloga in funkcije kmetijstva so se bistveno spremenile ob vključitvi Slovenije v Evropsko unijo (EU), spremembah v skupni kmetijski politiki EU ter splošni ekologizacija družbe, hkrati pa se ta proces sprememb še nadaljuje. Neposredni gospodarski pomen in učinki kmetijstva se tako še naprej zmanjšuje, hkrati pa v ospredje stopajo povsem nove funkcije te dejavnosti skupaj s povsem novo vlogo podeželja kot celote.

Prav bližina mesta pa vnaša v kmetijsko dejavnost in pridelavo MOL-a določene posebnosti. Kmetijstvo je še vedno v določeni meri dober skrbnik naravnih virov, v primestnem prostoru (zaledju) pa ključen oblikovalec pokrajinskega videza (Maslo, 2002). Hkrati je kmetijstvo v oziroma na obrobju mest zaradi različnih omejitvenih dejavnikov veliko bolj izpostavljeno, ranljivo, odziv na večjo ranljivost pa je večja prilagodljivost kmetijstva zaradi strukturnih, predvsem tržnih in socialnih sprememb (Kladnik, 2002).

Zanimivo je, da je Kavčič še leta 1985 glede na takratno stanje kmetij (starost gospodarjev in nasledstvo) sklepal, da bo treba tudi v prihodnosti računati na približno enako število kmetov in počasno koncentracijo zemljišč (leta 1981 je bilo na območju MOL okrog 4000 kmetov). Vendar se je proces zmanjševanja števila kmetij odvijal bistveno hitreje, vzporedno pa tudi procesi opuščanja obdelave kmetijskih zemljišč. Pričakovati je, da se bo v skladu s procesi in trendi na nivoju države proces opuščanja kmetijstva še nadaljeval, smiselno (z vidika MOL) pa bi bilo spodbujati čiste in mešane kmetije, tržno usmerjene in hkrati tiste, ki lahko polno zaposlijo vsaj eno polnovredno delovno moč (PDM). Prednost pri spodbujanju razvoja pa bi morale imeti tudi kmetije, ki svojo dejavnost razvijajo v skladu z okoljsko občutljivostjo in poizkušajo minimizirati snovne agrarne vnose, ki so okoljsko najbolj sporni.

Kljub temu, da območje MOL gravitira na državno središče (Ljubljano), se v zaledju že srečujemo z očitnimi spremembami v pokrajini. Neobdelana in zaraščena zemljišča kažejo na pojav razkroja kulturne pokrajine, ki se marsikdaj dopolnjuje še z neurejenimi odlagališči odpadkov, prisotnostjo propadajočih stanovanjskih in gospodarskih objektov ipd.

Kmetijska zemljišča v uporabi so predvsem na kmetijsko najugodnejših, ravninskih območjih Slovenije intenzivno obdelana, kar pa pogosto vpliva na zmanjšano kakovost naravnih virov, na manjšo biološko raznovrstnost in širše na prostor in celotno pokrajino. Vendar tudi ekstenzivnejše oblike kmetovanja (npr. v zaledju občine) igrajo pomembno pozitivno vlogo v odnosu do ohranjanja naravnih virov. Prostor kot t.i. neobnovljiv naravni vir, ki je namenjen kmetovanju, predstavlja enega ključnih naravnih virov, ki ima na območju državnega središča še toliko večjo vrednost. Spremembe v kmetovanju (pa ne le tiste, povezane z intenzifikacijo 
v kmetijstvu ter posledično povečanjem snovnih vnosov) tako ogrožajo tudi bodočo zunanjo in funkcionalno podobo kulturne pokrajine na širšem območju MOL.

Na stanje naravnih virov posredno vplivajo tudi spremembe v kmetijski politiki, preko povečevanja podpor, kjer financiranje ni povezano z neposredno kmetijsko proizvodnjo. Pomemben delež sredstev v okviru Programa razvoja podeželja je namenjen prav vzdrževanju pokrajine, okolja (ohranjanje naravnih danosti, ohranjanje naravnih virov), v omejenem obsegu pa tudi izboljšanju stanja v okolju. Vendar so razmere na območju MOL tudi v tem segmentu na nivoju Slovenije specifične, saj se kmetijsko-okoljski ukrepi, izvajajo v razmeroma skromnem obsegu. Na to opozarjajo podatki, da so se od skupnih 4576 ha KZU v MOL, ukrepi SKOP-a v letu 2004 izvajali na 1270 ha (dobrih 25 \%) kmetijskih zemljišč, medtem ko so se ukrepi na celotnem območju Slovenije istega leta izvajali na več kot 277.400 ha oziroma več kot 50 \% kmetijskih zemljišč.

\section{METODOLOŠKA IZHODIŠČA}

Ker naravnogeografske značilnosti pogojujejo usmeritev kmetijske dejavnosti in do neke mere tudi njeno intenzivnost kot tudi regeneracijske sposobnosti okolja ob različnih (kmetijskih) pritiskih, smo v samem izhodišču izhajali iz treh značilnih naravnih območij MOL. V neposredni bližini samega mesta Ljubljane je to ravninsko območje (predvsem območje Ljubljanskega polja), kjer so kmetijska zemljišča najboljša, hkrati pa se njihov pretežen del nahaja na območjih vodovarstvenih pasov, kar zahteva določene omejitve v kmetijstvu. Drugo značilno naravno območje je na širšem območju Barja na pretežno oglejenih tleh, kjer je kmetovanje do določene mere omejeno tako zaradi prsti kot specifičnih vodnih razmer. Tretje naravnogeografsko in pridelovalno območje pa je hribovito območje MOL oz. območje v Posavskem hribovju (po naravnih značilnostih sem uvrščamo še območje Rašice).

Preučevanje najnovejših razmer je temeljilo na neposredni raziskavi na terenu in sicer s pomočjo anketnega vprašalnika. Z anketo smo zajeli 189 (okrog $30 \%$ vseh) aktivnih kmetij na območju MOL in sicer v vseh treh značilnih pridelovalnih območjih, saj je eden pomembnih ciljev ugotoviti usmeritve in trende razvoja po posameznih značilnih območjih in hkrati pomembne razlike znotraj MOL. V prispevku je predstavljen le segment raziskave, podatki pa dajo vpogled v naslednja vsebinska polja;

- Splošne značilnosti posamezne kmetije.

- Vizijo razvoja širšega območja posamezne anketirane kmetije; na podlagi zaprtega vprašalnika so kmetje lahko izbrali po svoji oceni najbolj realno vizijo razvoja območja, vprašanje pa je dopuščalo več odgovorov, tako da smo na koncu dobili skupaj 243 odgovorov.

- Oceno posameznega kmeta o bodočem razvoju kmetije; kmetje so se lahko opredelili, da bo kmetija v bodoče ostala v okviru obstoječega obsega in usmeritve, da se na kmetiji odpirajo nove možnosti za kmetijsko dejavnost (povečanje obsega, sprememba usmeritve, vlaganja v kmetijo (stroje, hlev), vlaganje v dopolnilne dejavnosti) ali pa, da kmetija nima prave vizije in možnosti za obstoj (postopno opuščanje, opustitev kmetovanja). 
- Opredelitev najbolj perečih okoljskih problemov, kjer so se kmetje spet na podlagizaprtega vprašalnika odločali med enajstimi možnostmi, možnih pa je bilo več odgovorov. Na koncu smo skupaj dobili 368 odgovorov.

Na podlagi pridobljenih podatkov smo izračunali tudi energetsko intenzivnost posamezne kmetije ter povprečno energetsko intenzivnost kmetij na posameznem pridelovalnem območju in celotni MOL, kar omogoča sintezno vrednotenje vloge kmetijstva kot okoljskega obremenjevalca. Pri izračunavanju energetske intenzivnosti kmetijstva se upoštevajo naslednji vnosi: organska - živinska gnojila (gnoj, gnojnica, gnojevka), mineralna gnojila, sredstva za varstvo rastlin (količina porabljenih fungicidov, baktericidov, herbicidov, insekticidov in drugih), tekoča goriva (nafta, bencin, mešanica idr.) in električna energija. Uporabljena metodologija se je razvijala zadnjih 30 let (temelje je opredelil v 70-ih letih Slesser), v zadnjih desetih letih pa smo jo na številnih primerih preverili in dopolnili tudi na različnih območjih ter podali splošne ocene energetske intenzivnosti kmetijstva za celo Slovenijo (Radinja, 1996, Rejec Brancelj, 2000, Lampič, 2002).

\section{VIZIJE RAZVOJA OBMOČJA MOL IN PERSPEKTIVNOST KMETIJSTVA}

Prostor predstavlja enega ključnih neobnovljivih naravnih virov, zato smo konflikte kmetijstva $\mathrm{z}$ drugimi dejavnostmi $\mathrm{v}$ prostoru ugotavljali tudi neposredno na terenu, $\mathrm{s}$ pomočjo anketiranja kmetov. Ker je kmetijstvo večinoma odvisno od ustreznega obsega pridelovalnih površin (izjema je le intenzivna pridelava vrtnin in sadik v rastlinjakih), smo osvetlili perspektivnost kmetijstva s subjektivnim pogledom kmetov na možnosti obstoja in razvoja kmetijstva ter njihovimi vizijami razvoja prostora. Stališča in videnje kmetov kot pomembnih »upravljavcev« kmetijske zemlje v tem kontekstu predstavljajo dragocene informacije, saj se na območju MOL srečujemo z neustreznimi trendi razvoja rabe prostora (zaraščanjem, ozelenjevanjem, pozidavo), neusklajenostmi s predvideno rabo po strategiji razvoja kmetijstva, predvsem pa s pomanjkanjem prostora za razvoj obstoječih in novih dejavnosti.

Glede bodočega razvoja območja občine oziroma bodoče rabe prostora smo kmete povprašali, kako vidijo širše območje kmetije čez nekaj let.

Na velik pritisk urbanizacije kaže dejstvo, da je kar 42 \% anketiranih navedlo možnost, da bo širše območje kmetije čez leta del stanovanjskega naselja. Po drugi strani pa je zanimivo, da jih je skoraj $25 \%$ mnenja, da bo v bodoče njihova bližnja okolica vse bolj zaraščena $\mathrm{z}$ gozdom. Če upoštevamo še pomemben delež odgovorov (20 \%), ki so navedli za vizijo območja kategorijo drugo (večinoma so tu navajali opuščanje kmetovanja), se delež tistih, ki v prostorskem razvoju vidijo predvsem zaraščanje in opuščanje kmetovanja še poveča.

Rezultati so še mnogo bolj zanimivi, če ovrednotimo odgovore po različnih pokrajinskih območjih. Najbolj deljeni (in pogosto nasprotujoči si) so odgovori anketirancev na barjanskem območju, kjer jih kar $62 \%$ ocenjuje, da se bodo na širše območje kmetij v prihodnjih letih razširile stanovanjske soseske. Takšni odgovori so pričakovani, saj smo prav 
v zadnjem obdobju priče izjemno hitri pozidavi (s sicer manjšimi stanovanjskimi enotami) tega dela občine. Po drugi strani pa jih je skoraj četrtina (24 \%) navedla, da se bo območje postopoma zaraslo. Skoraj $28 \%$ anketiranih kmetov vidi barjansko območje v prihodnosti kot zavarovano območje, kar je glede na aktivnosti v zvezi z ustanavljanjem krajinskega parka Barje razumljivo. Kmetje so dobro seznanjeni s postopki ustanavljanja zavarovanega območja, zato ne preseneča, da jih pomemben delež vidi v zakonskem zavarovanju dela barjanskega območja možnost za ublažitev procesov hitrega spreminjanja rabe zemljišč (predvsem pozidave) in ustavitev zaraščanja.

Preglednica 1: Vizija razvoja območja (kmetov) v prihodnosti

Table 1: The future development vision of farmers

\begin{tabular}{|c|c|c|c|c|c|c|c|c|c|c|c|}
\hline & \multicolumn{7}{|c|}{ Vizija razvoja območja v prihodnosti } & & \multirow{2}{*}{ Skupaj } \\
\hline & & & 1 & 2 & 3 & 4 & 5 & 6 & 7 & 8 & \\
\hline \multirow{6}{*}{$\begin{array}{l}\underset{1}{0} \\
0 \\
0 \\
0 \\
0\end{array}$} & \multirow{2}{*}{$\begin{array}{l}\text { Barjansko } \\
\text { območje }\end{array}$} & Število & 7 & 0 & 18 & 1 & 2 & 8 & 1 & 5 & 42 \\
\hline & & $\begin{array}{l}\text { \% znotraj } \\
\text { območja }\end{array}$ & 24,1 & 0 & 62,1 & 3,4 & 6,9 & 27,6 & 3,4 & 17,2 & 17,3 \\
\hline & \multirow{2}{*}{$\begin{array}{l}\text { Hribovito } \\
\text { območje }\end{array}$} & Število & 38 & 12 & 18 & 2 & 9 & 2 & 4 & 26 & 111 \\
\hline & & $\begin{array}{l}\text { \% znotraj } \\
\text { območja }\end{array}$ & 44,2 & 14 & 20,9 & 2,3 & 10,5 & 2,3 & 4,7 & 30,2 & 45,7 \\
\hline & \multirow{2}{*}{$\begin{array}{l}\text { Ravninsko } \\
\text { območje }\end{array}$} & Število & 1 & 2 & 42 & 7 & 15 & 8 & 9 & 6 & 90 \\
\hline & & $\begin{array}{l}\text { \% znotraj } \\
\text { območja }\end{array}$ & 1,4 & 2,8 & 58,3 & 9,7 & 20,8 & 11,1 & 12,5 & 8,3 & 37,0 \\
\hline \multirow{2}{*}{\multicolumn{2}{|c|}{ S K UPA J }} & Število & 46 & 14 & 78 & 10 & 26 & 18 & 14 & 37 & 243 \\
\hline & & $\begin{array}{l}\text { \% znotraj } \\
\text { območja }\end{array}$ & 24,6 & 7,5 & 41,7 & 5,3 & 13,9 & 9,6 & 7,5 & 19,8 & 100 \\
\hline
\end{tabular}

1 - zaraščeno z gozdom; 2 - območje/naselje počitniških hišic; 3 - stanovanjsko naselje; 4 - območje, namenjeno trgovini, obrti, industriji; 5 - brez večjih sprememb; 6 - zavarovano območje; 7 - nimam predstave; 8 - drugo

Vir: Terensko delo 2006, 2007. UL, FF, Oddelek za geografijo

Source: Field work 2006, 2007. UL, FF, Oddelek za geografijo

Anketiranci hribovitega območja vidijo v prihodnosti predvsem še bolj zaraščeno okolje (44 \%), skoraj tretjina vprašanih pa meni, da bo na tem območju v bodoče kmetijska dejavnost vse manj prisotna. Pomemben delež predstavljajo tudi odgovori tistih kmetov, ki vidijo v hribovitem zaledju Ljubljane v prihodnosti razvoj območij počitniških hišic.

Povsem drugačna pa je slika na ravninskem območju, kjer kmetje v bodočnosti vidijo predvsem razširitev stanovanjskih sosesk (58 \%), delež ostalih odgovorov je manj pomemben. $\mathrm{Na}$ izjemen pritisk urbanizacije posredno kaže največji delež odgovorov (skupaj kar 80 \%), da bo čez leta ta predel bodisi stanovanjsko naselje, območje namenjeno trgovini, obrti, industriji oz. odgovor, da nimajo predstave o prihodnosti tega območja.

Če zgornje odgovore dopolnimo še z odgovori kmetov glede perspektivnosti njihove kmetije, dobimo celovit vpogled v problematiko obstoja oz. »sobivanja « kmetijstva z drugimi 
dejavnostmi na območju MOL. Glede razvojne prihodnosti kmetij gre največje spremembe pričakovati na barjanskem območju, kjer velik delež anketiranih kmetij načrtuje postopno ali razmeroma hitro opustitev kmetovanja, po drugi strani pa precejšnji delež kmetov razmišlja tudi o novih možnostih razvoja kmetije.

Ocene samih kmetov o perspektivnosti kmetije kažejo, da jih 67 \% namerava obdržati ali povečati dosedanji obseg obdelave in pridelave na kmetiji, $33 \%$ pa je takšnih, ki prave vizije za svojo kmetijo ne vidijo več. Poudariti pa velja, da je samo 14 (7\%) kmetij, ki dejansko načrtujejo opustitev kmetovanja, medtem ko preostali načrtujejo predvsem zmanjšanje obsega pridelave. Kot pomemben dejavnik pri odločitvi glede prihodnosti kmetije se kaže gospodarski vidik kmetovanja, saj opustitev kmetovanja načrtujejo le kmetije, ki dohodka iz kmetijstva nimajo oziroma je manjši od $25 \%$.

\section{KMETIJSKI VNOSI IN NJIHOVI VPLIVI NA NARAVNE VIRE}

Kmetovanje je tako točkoven kot ploskoven onesnaževalec v prostoru. Na okolje lahko negativno vplivajo neustrezni kmetijski postopki (časovno neustrezno in preobilno gnojenje, neustrezna uporaba sredstev za varstvo rastlin, neustrezna mehanizacija, pregloboko oranje, neustrezno vrstenje poljščin, neupoštevanje kolobarja idr.), najbolj neposredne negativne učinke v okolju pa povzročijo okoljsko sporni vnosi v kmetijstvu, katerih uporabo bomo predstavili v nadaljevanju.

Kmetijstvo na območju MOL je v primerjavi s slovenskimi razmerami nadpovprečno specializirano, prav tako je raven intenzifikacije višja od povprečne slovenske stopnje. Takšno stanje gre predvsem na račun večine kmetij na ravninskem in deloma barjanskem območju.

\section{I Najbolj pereči snovni agrarni vnosi}

Med okoljsko pereče snovne agrarne vnose uvrščamo organska in mineralna gnojila, sredstva za varstvo rastlin, na okolje pa negativno lahko vplivajo tudi naftni derivati, ki v sodobnem kmetijstvu predstavljajo pomemben energetski vir. Med okoljsko bolj sporrne nedvomno sodijo gnojila, najbolj negativne posledice pa v okolju povzročajo prekomerne količine dušika. Vir dušika organskega izvora so ostanki rastlinske pridelave (hlevski gnoj, gnojevka, gnojnica), mineralnega izvora pa številna mineralna gnojila. Prvi je za okolje manj pereč, vendar se v procesih mineralizacije dušika organska snov pretvori v mineralno, ki potem kroži v okolju v odvisnosti od naravnih razmer in pa porabe dušika. Teh procesov pa se ne da nadzorovati in jih ni mogoče uskladiti s časom, rastjo in razvojem rastlin. Po drugi strani pa je mineralen dušik zelo podvržen izpiranju, zato je pomembno, da ga vnašamo takrat, ko ga rastline dejansko potrebujejo.

Snovni vnosi (predvsem organska in mineralna gnojila) imajo lahko v prvi vrsti negativen vpliv na vode, predvsem na podtalnico, na prst, rastline (kmetijske pridelke) pa tudi na zrak. Kako in v kakšnem obsegu se bodo negativni okoljski učinki vseh omenjenih vnosov odražali v okolju, pa je odvisno od številnih dejavnikov in sicer od lastnosti prsti (debeline, kationske izmenjalne kapacitete, $\mathrm{pH}$ idr., (Lampič, 2000), podnebja, rabe tal (vrsta 
rabe, pokritost zemljišč idr.), načina in količine gnojenja, uporabe sredstev za varstvo rastlin, načina obdelave tal idr..

Opredeljene dovoljene mejne vrednosti števila glav velike živine iz predpisa, ki ureja vnos nevarnih snovi in rastlinskih hranil v tla (do 1,9 GVŽ/ha), kar $95 \%$ anketiranih kmetij v MOL izpolnjuje predpisane pogoje. Glede na prevladujoč delež govedorejskih (42\%) in mešanih kmetij (35 \%) so podatki o reji živine oziroma živinorejski gostoti prav pri okoljskem vrednotenju še kako pomembni. (Lampič s sodelavci, 2007)

Povprečno slovensko kmetijsko gospodarstvo, usmerjeno v živinorejo, po zadnjih podatkih redi skoraj 7 glav velike živine. Podobno kakor v drugih državah EU se obtežba tudi v Sloveniji zmanjšuje, samo v obdobju 1997-2003 za skoraj 10 \% (v povprečju se je spustila pod 1 glavo velike živine na hektar kmetijskih zemljišč v uporabi).

Preglednica 2: Osnovne karakteristike anketiranih kmetij v MOL

Table 2: Characteristics of farms in Municipality of Ljubljana

\begin{tabular}{|l|c|c|c|c|c|}
\hline & $\begin{array}{c}\breve{S} \text { Stevilo } \\
\text { kmetij }\end{array}$ & $\begin{array}{c}\text { Obdelovalna zemljišča } \\
\text { v ha - skupaj }\end{array}$ & $\begin{array}{c}\text { GVŽ- } \\
\text { skupaj }\end{array}$ & $\begin{array}{c}\text { GVŽ na } \\
\text { kmetijo }\end{array}$ & $\begin{array}{c}\text { Živinorejska } \\
\text { gostota }\end{array}$ \\
\hline Barjansko območje & 30 & 708,7 & 652 & 21,7 & 0,9 \\
\hline Hribovito območje & 87 & 661,9 & 606 & 7,0 & 0,9 \\
\hline Ravninsko območje & 72 & 914,2 & 933 & 13,0 & 1,0 \\
\hline SKUPAJ & 189 & 2284,8 & 2191 & 11,6 & 1,0 \\
\hline
\end{tabular}

Vir: Terensko delo 2006, 2007. UL, FF, Oddelek za geografijo

Source: Field work 2006, 2007. UL, FF, Oddelek za geografijo

Podobni trendi se kažejo tudi v ljubljanski občini. V povprečju anketirane kmetije gojijo $1 \mathrm{GVŽ/ha} \mathrm{obdelovalnih} \mathrm{zemljišč,} \mathrm{po} \mathrm{posameznih} \mathrm{pridelovalnih} \mathrm{območjih} \mathrm{pa} \mathrm{se} \mathrm{kaže,}$ da je živinorejska gostota na barjanskem in v hribovitem območju še nekoliko nižja. Samo na desetih kmetijah (5 \% anketiranih) je živinorejska gostota večja od 2 GVŽ/ha, pet jih je na ravninskem območju. Te kmetije predstavljajo potencialno nevarnost za obremenjevanje podtalnice. Največji delež kmetij ima živinorejsko gostoto pod 1, 34 \% pa od 1 do $2 \mathrm{GVŽ/ha.}$ Nekoliko povečane obtežbe z živino se pojavljajo na ravninskem območju in pri posameznih kmetijah v hribovitem delu, vendar trenutno stanje kaže na okoljsko ugodno sliko. Tudi največja živinorejska kmetija (s 340 GVŽ) na barju ima ustrezno obtežbo obdelovalnih površin, saj razpolagajo z zadostnimi količinami obdelovalne zemlje. (Lampič s sodelavci, 2007)

Podobno kot se zmanjšuje obtežba z živino se je v Sloveniji v obdobju 1992-2005 zmanjšala tudi skupna količina porabljenih mineralnih gnojil in sicer za 27,0 \%. Najbolj se je zmanjšala poraba dušika (33,5 \%), sledi kalij (27,0 \%) in fosfor (15,3 \%). Zmanjšala se je tudi poraba mineralnih gnojil na hektar kmetijske zemlje v uporabi in sicer za 16,3 \% oziroma od $342 \mathrm{~kg} / \mathrm{ha}$ na $294 \mathrm{~kg} / \mathrm{ha}$ (Medmrežje 2, Kazalci okolja, 2007).

Zmanjšanje porabe mineralnih gnojil na hektar kmetijskih zemljišč v uporabi gre pripisati zahtevam nitratne direktive in načelom dobre kmetijske prakse pri gnojenju, $\mathrm{h}$ katerim so zavezana kmetijska gospodarstva v zadnjih letih, še posebej pa po letu 2004, ko 
Slika 1: Raba mineralnih gnojil na anketiranih kmetijah

Figure 1: The use of mineral fertilizers on farms

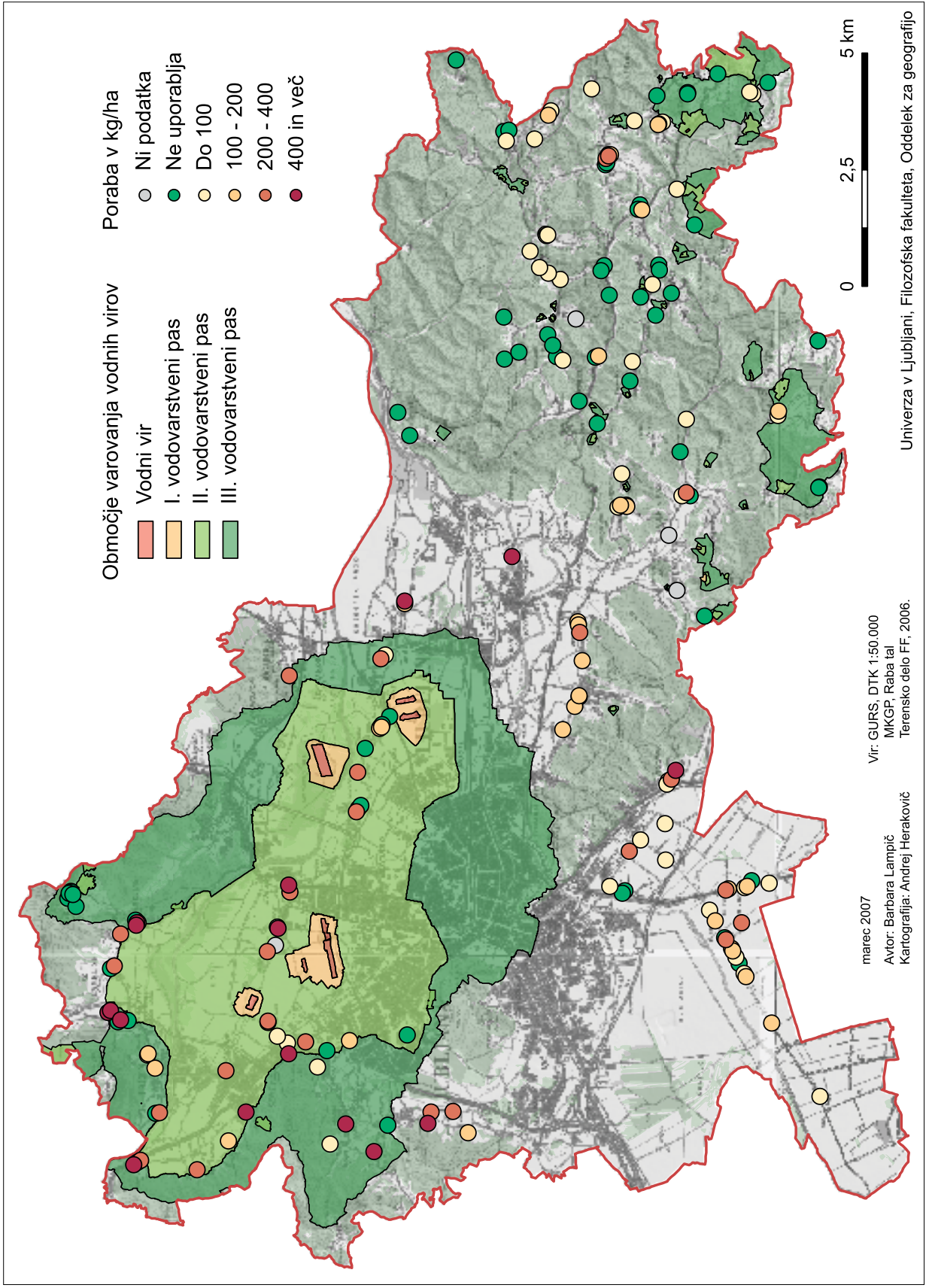


smo vstopili v EU. Oba dokumenta posvečata večjo pozornost uporabi živinskih gnojil ter upoštevanju rastlinskih hranil v živinskih gnojilih pri načrtovanju gnojenja z mineralnimi gnojili. Ker morajo imeti kmetijska gospodarstva izdelane gnojilne načrte, v katerih so ovrednotena tudi uporabljena rastlinska hranila iz živinskih gnojil, se poraba mineralnih gnojil temu ustrezno zmanjšuje. Ti trendi se odražajo tudi pri interpretaciji aktualnih razmer na kmetijah MOL, hkrati pa je potrebno opozoriti na dejstvo, da so kmetje v veliki večini vseeno nekoliko podcenili obseg porabe mineralnih gnojil.

Med anketiranimi kmetijami prevladuje delež tistih, ki porabijo v povprečju do 100 $\mathrm{kg}$ mineralnih gnojil na ha (29 \% kmetov). Nasploh pa je kar $35 \%$ anketirancev zatrdilo, da mineralnih gnojil sploh ne uporabljajo. Največ takih je bilo v hribovitem območju (54 \%), najmanj pa na ravninskem (19\%). Delež kmetov z večjo hektarsko porabo mineralnih gnojil je nasploh največji na ravninskem območju, kjer je tudi intenzivnost kmetovanja največja, hkrati pa okolje najbolj občutljivo. Skoraj $50 \%$ ravninskih kmetij porabi v povprečju več kot $200 \mathrm{~kg}$ mineralnih gnojil na ha. Te številke so v skladu s povprečnim stanjem v Sloveniji, vendar je potrebno izpostaviti, da bodo aktivnosti za zmanjševanje porabe mineralnih gnojil na ravninskem delu občine še potrebne.

Prostorska razporeditev kmetij v MOL glede na uporabo sredstev za varstvo rastlin kaže določene specifike. Uporaba sredstev za varstvo rastlin (SVR) je v MOL omejena na ravninski in barjanski del, medtem ko jih kmetje v vzhodnem hribovitem območju skoraj ne uporabljajo oziroma jih uporabljajo le posamezne v sadjarstvo usmerjene kmetije. Za razliko od porabe mineralnih gnojil je poraba SVR v Sloveniji v zadnjih desetih letih dokaj konstantna z manjšimi nihanji. Njihova poraba na hektar obdelovalnih površin je v Sloveniji nad povprečjem držav EU-15, je pa primerljiva s porabo v državah s podobno strukturo gojenih rastlin in podobnimi pridelovalnimi razmerami (Medmrežje 2, Kazalci okolja, 2007).

\subsection{Energetska intenzivnost kmetijstva in struktura energetskih vnosov}

Energetska intenzivnost kmetijstva je eden od najbolj sinteznih načinov, s katerim je moč prikazati kmetijsko obremenjevanje okolja. Ker je z okoljevarstvenega vidika predvsem pereče obremenjevanje z gnojili, sredstvi za varstvo rastlin in tekočimi gorivi, so izračuni energetske intenzivnosti za posamezna območja narejeni na različnem obsegu vnosov. Osnovni vključuje prej omenjene, dodatni pa še električno energijo.

Poraba energije v kmetijstvu je postala tudi primerljiv okoljski kazalec evropske okoljske statistike. Poraba energije je izražena z neposredno porabo plinskega olja, bencina in električne energije ter s posredno porabo za proizvodnjo mineralnih gnojil. Po tej metodologiji predstavlja v Sloveniji večji del energijske porabe v kmetijstvu plinsko olje za pogon naftnih strojev (49,6\%), sledi energija za proizvodnjo mineralnih gnojil (42,6\%) in električna energija (4,6 \%). Za leto 2000 se ocenjuje, da je bilo na ha obdelovalnih površin porabljenih 10,3 GJ/ ha (od tega 4,4 GJ/ha za proizvodnjo mineralnih gnojil), poraba plinskega olja se po letu 1996 zmanjšuje. Ker v Sloveniji ne proizvajamo mineralnih gnojil, ta energija sicer ne vpliva na nacionalno energijsko bilanco, posredno pa prav tako obremenjuje okolje z ogljikovim dioksidom (Medmrežje, Kazalci okolja, 2007). 
Takšno energetsko vrednotenje kmetijstva je mogoče samo na državnem nivoju in je namenjeno vrednotenju doseganja ciljev Kjotskega protokola - zmanjševanju izpustov toplogrednih plinov, kjer ima pomembno mesto tudi kmetijstvo.

Metodologija energetskega vrednotenja kmetijstva na podlagi podatkov o snovnih in energetskih vnosov na sami kmetiji ima bistveno večjo uporabno vrednost, predvsem pa omogoča kompleksno vrednotenje dejanskih pritiskov kmetijstva na okoljske sestavine (ne le na zrak, kar nakazuje prej omenjena državna metodologija).

Obstoječe raziskave v Sloveniji kažejo, da se je povprečna energetska intenzivnost slovenskih kmetij konec 90 -ih gibala med 30 in $38 \mathrm{GJ} /$ ha obdelovalnih zemljišč (Rejec Brancelj, 2000, Lampič, 2002). Na kmetijsko najprimernejših in pridelovalno intenzivnejših območjih, predvsem prodnih ravnicah, pa je ta vrednost še višja, med 35 in $46 \mathrm{GJ} / \mathrm{ha}$ ).

Preglednica 3: Energetska intenzivnost (EI) kmetij v MOL

Table 3: Energetic intensity of farms in Municipality of Ljubljana

\begin{tabular}{|l|cc|c|cc}
\hline \multicolumn{2}{|c}{$\begin{array}{c}\text { Število } \\
\text { anketiranih } \\
\text { kmetij }\end{array}$} & $\begin{array}{c}\text { Obdelovalne } \\
\text { površine (ha) }\end{array}$ & $\begin{array}{c}\text { Število } \\
\text { GVŽ }\end{array}$ & $\begin{array}{c}\text { Skupna EI } \\
\text { (GJ/ha) }\end{array}$ & $\begin{array}{c}\text { EI - brez } \\
\text { električne } \\
\text { energije } \\
\text { (GJ/ha) }\end{array}$ \\
\hline Barjansko območje & 30 & 708,7 & 652,47 & 21,8 & 9,2 \\
\hline Hribovito območje & 87 & 661,85 & 609,49 & 25,3 & 9,5 \\
\hline Ravninsko območje & 72 & 914,21 & 929 & 31,3 & 17,6 \\
\hline MOL & 189 & 2284,76 & 2190 & 27,0 & 12,5 \\
\hline
\end{tabular}

Vir: Terensko delo 2006, 2007. UL, FF, Oddelek za geografijo

Source: Field work 2006, 2007. UL, FF, Oddelek za geografijo

Najnovejši podatki in izračuni za MOL kažejo pomembno drugačno sliko. Povprečna energetska intenzivnost kmetijstva ob upoštevanju vseh vnosov znaša $27 \mathrm{GJ} / \mathrm{ha}$, vendar se po posameznih območjih pomembno razlikuje. Tako se skromnejša intenzivnost kmetovanja kaže na barjanskem območju (21,8 GJ/ha), pričakovana največja pa na osrednjem ravninskem (31,3 GJ/ha). Meja, ko se negativni okoljski učinki začno širiti iz kmetije v okolje je $15 \mathrm{GJ} / \mathrm{ha}$, vendar je precej pomembna tudi struktura energetskih vnosov.

Okoljsko gledano so tako bolj pomembni podatki o specifičnih agrarnih vnosih. Izstopa seveda električna energija, vrednost tekočih goriv $(5,48 \mathrm{GJ} / \mathrm{ha})$ pa je blizu ocene za slovensko povprečje (Lampič, 2002). Ponovno je potrebno poudariti razlike med območji. Višjo porabo tekočih goriv na ravninskem delu občine lahko pripišemo na eni strani intenzivnejši kmetijski pridelavi, razmeroma veliki oddaljenosti in raztresenosti obdelovalnih površin (več prevozov), nezanemarljiv pa je tudi delež tekočih goriv, ki jih pridelovalci zelenjave porabijo za ogrevanje rastlinjakov. Višja vrednost porabe mineralnih gnojil pri barjanskih kmetijah je povezana $\mathrm{z}$ usmerjenostjo kmetij $\mathrm{v}$ govedorejo, kjer je za pridelavo krme (silažna koruza) $\mathrm{v}$ večjem obsegu potrebna uporaba mineralnih gnojil.

Ker posamezne vrste energetskih vnosov okolje različno obremenjujejo (različna okoljska teža vnosov), je bolj kot skupna poraba pomembna njihova struktura. Glede strukture vnosov se je pokazalo, da na območju MOL, upoštevajoč vse energetske vnose, največji ener- 
Preglednica 4: Vrednosti energijske porabe posameznih agrarnih vnosov v GJ/ha Table 4: Values of energy consumption of agricultural inputs in GJ/ha

\begin{tabular}{|l|c|c|c|c|c|c|}
\hline & $\begin{array}{c}\text { hlevski } \\
\text { gnoj }\end{array}$ & $\begin{array}{c}\text { gnojnica, } \\
\text { gnojevka }\end{array}$ & $\begin{array}{c}\text { mineralna } \\
\text { gnojila }\end{array}$ & SVR & $\begin{array}{c}\text { Tekoča } \\
\text { goriva }\end{array}$ & $\begin{array}{c}\text { električna } \\
\text { energija }\end{array}$ \\
\hline Barjansko območje & 2,18 & 2,22 & 4,14 & 0,08 & 3,80 & 4,15 \\
\hline Hribovito območje & 3,03 & 1,24 & 0,64 & 0,03 & 4,46 & 12,88 \\
\hline Ravninsko območje & 3,18 & 1,81 & 3,50 & 0,07 & 7,52 & 7,72 \\
\hline MOL & 2,83 & 1,77 & 2,87 & 0,06 & 5,48 & 8,11 \\
\hline
\end{tabular}

Vir: Terensko delo 2006, 2007. UL, FF, Oddelek za geografijo

Source: Field work 2006, 2007. UL, FF, Oddelek za geografijo

Slika 2: Struktura kmetijskih vnosov na anketiranih kmetijah

Figure 2: The structure of agricultural inputs on farms

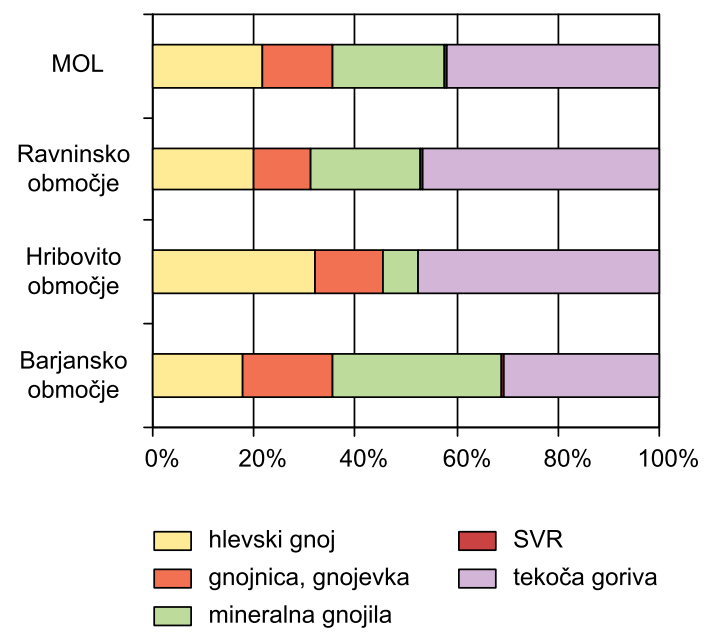

Vir: Terensko delo 2006, 2007. UL, FF, Oddelek za geografijo

Source: Field work 2006, 2007. UL, FF, Oddelek za geografijo

getski delež prispeva električna energija (39 \%), ki je okoljsko najmanj sporna, s $26 \%$ so na drugem mestu tekoča goriva, organska gnojila pa skupaj predstavljajo kar $21 \%$. Med slednjimi je okoljsko bolj sporen delež gnojevke in gnojnice (pronicanje v podtalnico, predvsem ob nepravilni uporabi). Mineralna gnojila predstavljajo $14 \%$ vnosov, medtem ko je energetski delež vnosa sredstev za varstvo rastlin zanemarljiv. Če naši izsledki kažejo, da se je v zadnjih letih nekoliko zmanjšala energetska intenzivnost v kmetijstvu, pa je presenetljivo sorodna ostala struktura energetskih vnosov.

Okoljsko bolj zanimiva je struktura le štirih vnosov in sicer organskih in mineralnih gnojil, sredstev za varstvo rastlin ter tekočih goriv. Struktura osnovnih agrarnih vnosov odraža pridelovalno usmeritev kmetijstva po posameznih območjih. Prav presenetljivo je 
dejstvo, da se struktura vnosov na nivoju občine skoraj povsem ujema s strukturo vnosov na nivoju Slovenije (Lampič, 2002). Hlevski gnoj tako predstavlja $22 \%$ (povsem enako), gnojevka in gnojnica 14 \% (Slovenija $15 \%$ ), mineralna gnojila $22 \%$ (Slovenija 24,6), delež SVR je na območju MOL zanemarljiv (zaradi lege kmetij na VVO jih velik delež teh sredstev ne uporablja, hkrati pa se večja poraba SVR kaže predvsem pri intenzivnem sadjarstvu), tekočih goriv pa 42 \% (Slovenija 37,1 \%) (Lampič, 2002, Lampič s sodelavci, 2007).

\subsection{Prostorska razporeditev agrarnih vnosov}

Slika energetske intenzivnosti po posameznih pridelovalnih območjih znotraj MOL je zelo generalizirana in ne pokaže dejanskih velikih razlik med posameznimi kmetijami, ki dosegajo intenzivnost do nekaj GJ/ha pa do 100 in več GJ/ha. Razlike v energetski intenzivnosti po posameznih pridelovalnih območjih so pričakovane, skoraj pa bi pričakovali še večje odstopanje ravninskih kmetij. Analiza energetske intenzivnosti je pokazala sledeče;

- Energetsko najbolj potratne kmetije (vnosi nad $35 \mathrm{GJ} / \mathrm{ha}$ ) se pojavljajo osrednjem območju Ljubljanskega polja, na območju vodovarstvenih pasov, izjemoma tudi v osrednjem hribovitem delu občine.

- Barjanske kmetije so praviloma energetsko manj intenzivne, večinoma imajo vnose med 15 in $25 \mathrm{GJ} / \mathrm{ha}$.

- V hribovitem zaledju obstajajo velike razlike med kmetijami, energetsko manj potratne pa so na skrajnem vzhodu in jugu občine.

- Od 189 anketiranih kmetij jih ima le 24 (12\%) energetsko intenzivnost nižjo od $15 \mathrm{GJ} / \mathrm{ha}$ (okoljsko še sprejemljiva meja), 54 pa jih presega $30 \mathrm{GJ} / \mathrm{ha}$.

Še bolj zanimiv pa je prikaz energetske intenzivnosti posameznih kmetij, ko upoštevamo samo osnovne štiri energetske vnose, ki pa so tudi okoljsko najbolj sporni (okoljsko sporne vnose organskih in mineralnih gnojil, sredstev za varstvo rastlin in tekočih goriv). $\mathrm{Na}$ celotnem barjanskem in hribovitem območju so kmetije glede na energetsko porabo okoljsko zelo sprejemljive. Izstopajo pa predvsem posamezne (največ v pridelavo zelenjave) usmerjene kmetije na ravninskem delu občine in sicer osrednjem delu Ljubljanskega polja. Posamezne dosegajo vnose preko $30 \mathrm{GJ} / \mathrm{ha}$, kar pa okoljsko ni več zanemarljivo, če upoštevamo še občutljivejše naravno okolje.

\subsection{Ocena vplivov kmetijstva na okolje}

Glavni vir vnosov nitratov v podtalnico je točkovno onesnaženje (neurejena skladišča živinskega gnojila in kanalizacija) ter razpršeno onesnaženje zaradi uporabe živinskega in mineralnega gnojila. Zaradi zmanjšanja obremenjevanja voda z nitrati velja v Sloveniji od leta 1996 omejitev obtežbe kmetijske zemlje z živino, predpisani pa so tudi okolju prijazni načini gnojenja kmetijskih zemljišč.

$\mathrm{Na}$ osnovi strukture energetskih vnosov in same energetske intenzivnosti kmetijstva na območju MOL lahko glede vplivov kmetijstva na zaloge vodnih virov predvidevamo sledeče: 
Slika 3: Energetska intenzivnost anketiranih kmetij (brez električne energije)

Figure 3: Energetic intensity of farms (without electricity)

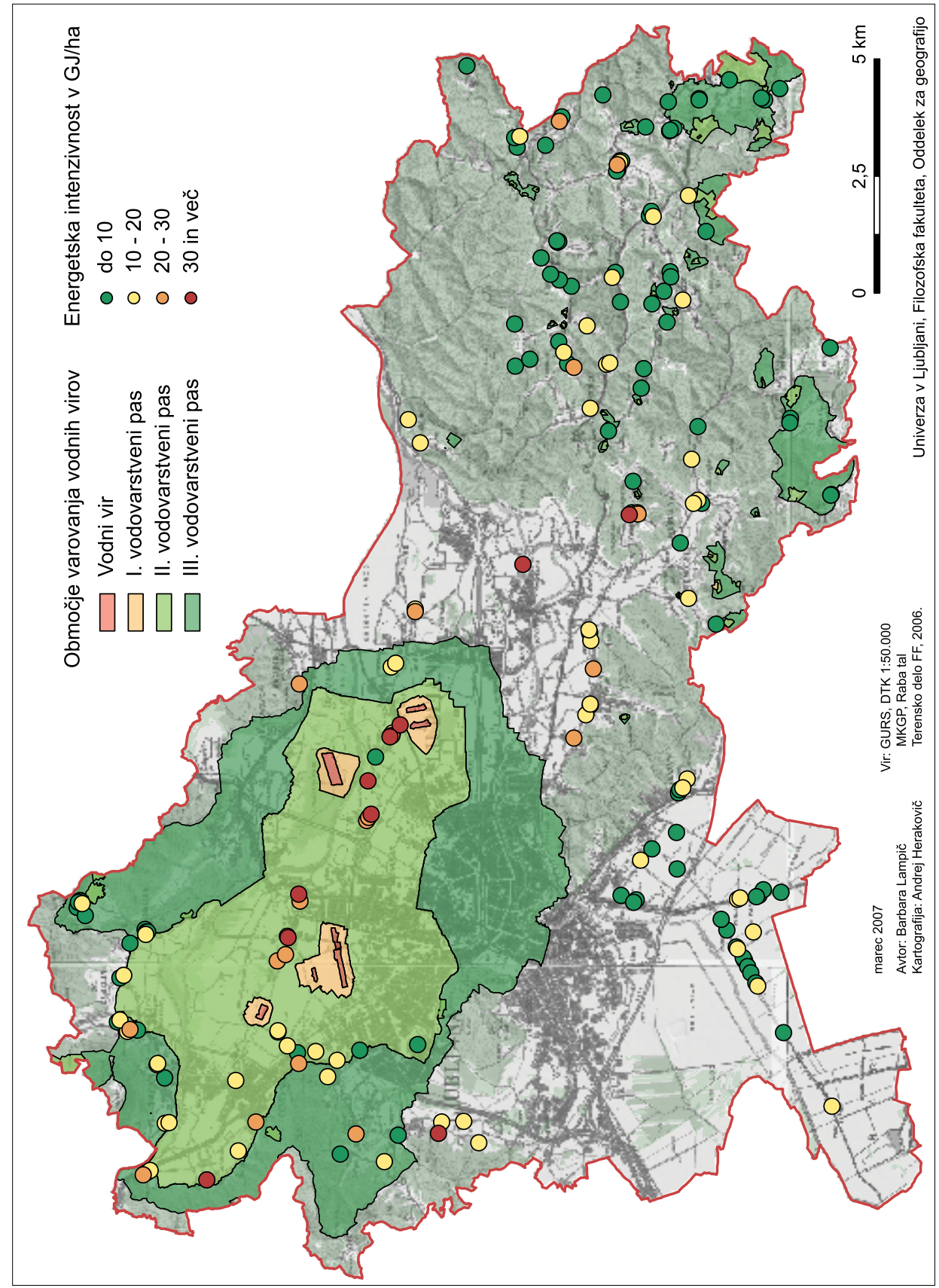


- Vrednosti energijske porabe vseh okoljsko bolj spornih vnosov so razmeroma nizke. To velja za vsa tri območja občine.

- Na barjanskem območju so nekoliko višje vrednosti vnosov gnojevke in gnojnice $(2,2$ $\mathrm{GJ} / \mathrm{ha}$ ) ter mineralnih gnojil (4,4 GJ/ha). Oba vnosa sta okoljsko bolj sporna, vendar so obstoječe vrednosti okoljsko še sprejemljive.

- V hribovitem delu po pričakovanjih (usmeritev kmetijstva) nekoliko izstopa vrednost hlevskega gnoja, ki pa je okoljsko manj sporen.

- Na ravninskem območju poleg hlevskega gnoja nekoliko izstopajo še vnosi tekočih goriv (7,5 GJ/ha), ta vrednost pa je z vidika slovenskih razmer povsem ustrezna in okoljsko manj sporna.

- Obseg in struktura agrarnih vnosov na celotnem območju MOL in po posameznih pridelovalnih območjih so po aktualnih podatkih $\mathrm{z}$ vidika varovanja vodnih virov primerni.

Tudi stanje podtalnice na Ljubljanskem polju kaže, da razen izjemoma kmetijstvo trenutno ne predstavlja kritičnega obremenjevalca okolja/voda. Vsi podatki kažejo, da je trenuten obseg vnosov vse ustreznejši (razen seveda izjemoma - med to povprečno ugodno sliko smo tudi med našim anketiranimi kmetijami našli posamezne okoljsko zelo sporne). Dosedanji ukrepi so pravilno zastavljeni, potrebna bi bila še nekoliko boljša kontrola in njihovo dosledno izvajanje.

\section{IZSTOPAJOČI OKOLJSKI PROBLEMI}

Kot dopolnitev k analizi navzkrižij med kmetijsko rabo in okoljem, pa tudi konfliktov med različnimi dejavnostmi v prostoru, smo $\mathrm{z}$ vprašalnikom med kmeti ugotavljali, kateri so izstopajoči »okoljski« problemi na širšem območju kmetije (delu mesta, naselju). V prvi vrsti smo želeli pridobiti informacijo o problemih iz okolice/okolja, ki kmetovalce in predvsem kmetijsko dejavnost najbolj motijo. Tako pridobljeni podatki niso objektivni, vendar pogled anketirancev oziroma njihovo dojemanje splošne okoljske problematike odraža videnje populacije kmetov, ki so se znašli ujeti med številne druge, pogosto prostorsko vse bolj agresivne dejavnosti.

Med možnimi odgovori so kmetje lahko izpostavili naslednje okoljske probleme: probleme povezane s prometom, neurejena kanalizacija, problemi s pitno vodo, onesnaženo ozračje, neurejena gnojišča, neurejena divja odlagališča odpadkov, stihijska oziroma slabo načrtovana gradnja, težave zaradi obiskovalcev, rekreativcev (prečkanje obdelovalnih površin, kraja, škoda ipd.), zaraščanje, druge motnje (divjad, vrtičkarji, idr.), lahko pa so se odločili tudi za odgovor, da v okolici bivanja ni izrazitih okoljskih problemov (6\% anketirancev).

V raziskavi kmetijstva znotraj AC obroča (Kladnik, 2002) se je na sicer nekoliko drugače formulirano vprašanje (glavne težave, ki jih povzroča kmetom okolica) pokazalo, da so za kmete na ožjem ljubljanskem območju najbolj pereči problemi povezani s škodo, ki jo povzročajo občani $(70 \%)$, otežen dostop do parcel zaradi gostega prometa $(60 \%)$ in težaven dostop do obdelovalnih zemljišč zaradi njihove oddaljenosti (35\%). 
Oba največja problema, kot sta bila ugotovljena za kmetije znotraj AC obroča, sta se pokazala kot relevantna tudi v naši raziskavi na večjem delu ravninskega območja občine.

Ker so anketiranci imeli možnost izbrati do tri izstopajoče okoljske probleme, smo dobili skupaj 368 odgovorov. Največkrat navedene okoljske motnje so t.i. drugi okoljski problemi (ki jih povzročajo vrtičkarji, divjad, hrup posameznih dejavnosti v naselju, poplavljanje, nenadzorovano nasipanje ipd.) in sicer je ta odgovor navedlo kar $49 \%$ anketirancev. Med ostalimi odgovori pa so najpogosteje navajali probleme povezane s prometom (34\%), neurejeno kanalizacijo (25\%) in motnje, ki jih povzročajo rekreativci oziroma izletniki (24 \%).

\section{Preglednica 5: Okoljski problemi kot jih vidijo anketiranci}

Table 5: Environmental problems from the farmers perspective

\begin{tabular}{|c|c|c|c|c|c|c|c|c|c|c|c|c|c|c|}
\hline & \multicolumn{11}{|c|}{ Okoljski problemi } & \multirow{2}{*}{$\begin{array}{c}\text { Sku- } \\
\text { paj }\end{array}$} \\
\hline & & & 1 & 2 & 3 & 4 & 5 & 6 & 7 & 8 & 9 & 10 & 11 & \\
\hline \multirow{6}{*}{ 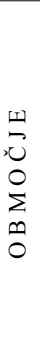 } & \multirow{2}{*}{$\begin{array}{l}\text { Barjansko } \\
\text { območje }\end{array}$} & Število & 15 & 16 & 0 & 1 & 3 & 8 & 1 & 3 & 6 & 10 & 1 & 64 \\
\hline & & $\begin{array}{l}\text { \% znotraj } \\
\text { območja }\end{array}$ & 50 & 53,3 & 0 & 3,3 & 10 & 26,7 & 3,3 & 10 & 20 & 33,3 & 3,3 & 17,4 \\
\hline & \multirow{2}{*}{$\begin{array}{l}\text { Hribovito } \\
\text { območje }\end{array}$} & Število & 8 & 17 & 23 & 1 & 1 & 8 & 3 & 10 & 14 & 58 & 7 & 150 \\
\hline & & $\begin{array}{l}\text { \% znotraj } \\
\text { območja }\end{array}$ & 9,2 & 19,5 & 26,4 & 1,1 & 1,1 & 9,2 & 3,4 & 11,5 & 16,1 & 66,7 & 8 & 40,8 \\
\hline & \multirow{2}{*}{$\begin{array}{l}\text { Ravninsko } \\
\text { območje }\end{array}$} & Število & 41 & 14 & 1 & 3 & 0 & 24 & 7 & 33 & 2 & 25 & 4 & 154 \\
\hline & & $\begin{array}{l}\text { \% znotraj } \\
\text { območja }\end{array}$ & 56,9 & 19,4 & 1,4 & 4,2 & 0 & 33,3 & 9,7 & 45,8 & 2,8 & 34,7 & 5,6 & 41,8 \\
\hline \multirow{2}{*}{\multicolumn{2}{|c|}{ S K U P A J }} & Število & 64 & 47 & 24 & 5 & 4 & 40 & 11 & 46 & 22 & 93 & 12 & 368 \\
\hline & & $\begin{array}{l}\text { \% znotraj } \\
\text { območja }\end{array}$ & 33,9 & 24,9 & 12,7 & 2,6 & 2,1 & 21,5 & 5,8 & 24,3 & 11,6 & 49,2 & 6,3 & 100 \\
\hline
\end{tabular}

1 - problemi povezani s prometom (gneča, parkiranje, hrup); 2 - neurejena kanalizacija; 3 - težave s pitno vodo (kakovost, občasno onesnažena, pomanjkanje...); 4 - onesnažen zrak; 5 - neurejena gnojišča (izcejanje, smrad...); 6 - neurejena, divja odlagališča odpadkov; 7 - stihijska, slabo načrtovana gradnja; 8 - motnje zaradi rekreativcev, izletnikov idr. obiskovalcev; 9 - vse večje zaraščanje; 10 - drugo (vrtičkarji, divjad, hrup drugih dejavnosti...); 11 - ni izstopajočih okoljskih problemov

Vir: Terensko delo 2006, 2007. UL, FF, Oddelek za geografijo

Source: Field work 2006, 2007. UL, FF, Oddelek za geografijo

Po posameznih pridelovalnih območjih so se pokazale pomembne razlike in sicer;

- Kmetje na barjanskem območju kot največji okoljski problem občutijo neurejeno kanalizacijo (53\%), probleme povezane s prometom (15 kmetov oz. $50 \%$ ), druge okoljske probleme (poplavljanje in nenadzorovano zasipanje) je navedlo $33 \%$ anketirancev, $27 \%$ pa jih motijo neurejena divja odlagališča.

- Sorodni okoljski problemi motijo anketirance na ravninskem območju in sicer so moteči problemi v prometu ( $57 \%$ ), na drugem mestu so motnje, ki jih povzročajo rekreativci (ter sprehajalci s psi) - ta problem je izpostavilo kar $46 \%$ kmetov tega območja, $35 \%$ pa je navedlo kot moteč t.i. drug problem, ki je na tem območju predvsem povezan s škodo, ki jo povzroča divjad (nekaj pridelovalcev zelenjave je izpostavilo celo vrane, ki trgajo 
folijo) in pa vrtičkarje. Slednji motijo kmete predvsem zaradi neprimernega odnosa do okolja (neustrezna vrtičkarska infrastruktura, način pridelave vrtnin idr.), hkrati pa povzročajo škodo na bližnjih kmetijskih zemljiščih.

- Na hribovitem območju občine je za kmete najbolj moteča divjad in slabo urejene ceste (t.im. drugi problemi $-67 \%$ ) ter težave s pitno vodo.

\section{SKLEP}

Ljubljana oziroma širše območje celotne Mestne občine Ljubljana je podvrženo hitrim in obsežnim spremembam, ki so predvsem posledice gospodarske vloge prestolnice. Kmetijstvo kot gospodarsko nekonkurenčna dejavnost se je na tem območju znašlo v specifični vlogi; ujeto med prodorne in hitro rastoče gospodarske dejavnosti, hkrati pa prostorsko še vedno zaseda pomemben delež vse dragocenejših »prostih«, torej nepozidanih površin. Najnovejša obsežna terenska raziskava, ki je bila osredotočena na še aktivne kmetije na območju celotne občine (Lampič s sodelavci, 2007), se je na eni strani lotila vrednotenja kmetijstva kot potencialnega obremenjevalca okolja, hkrati pa je v okviru temeljite analize demografskih in socio-ekonomskih potez obstoječih kmetij ovrednotila aktualno vlogo ter ocenila perspektive kmetijstva v občini pa tudi podrobneje, znotraj treh značilnih geografskih (in pridelovalnih) območij. Vsekakor predstavljeni rezultati, ki temeljijo na analizi razmer na približno 30 \% ljubljanskih aktivnih kmetij, razmeroma dobro odražajo stanje in trende v kmetijstvu celotne občine.

Glavne poudarke $\mathrm{z}$ vidika okoljske in razvojne vloge kmetijstva pa lahko strnemo v sledečih točkah:

Usmerjenost in specializiranost sicer maloštevilnih kmetij v MOL je vse večja (tudi glede na razmere v Sloveniji) predvsem pa se povečuje tudi njihova tržna angažiranost. Izobrazbena struktura gospodarjev, njihovih naslednikov in družinskih članov se postopoma izboljšuje, prihaja do postopnega preobrata $v$ miselnosti in delovanju kmetov in kmetij, kar se vse bolj že odraža v prostoru. Velik del obstoječih anketiranih kmetij načrtuje obdržati trenutni obseg in način pridelovanja ( $42 \%$ ) oziroma celo vidijo nove perspektive $v$ razvoju kmetije (skoraj $25 \%$ ), torej skupaj skoraj $70 \%$ kmetij v MOL načrtuje bodisi nadaljnji razvoj svoje dejavnosti ali vsaj zadržati obstoječe stanje. Hkrati pa je od vseh anketiranih skoraj 80 $\%$ kmetij vsaj v enem segmentu pridelave tržno naravnanih.

Trendi razvoja kmetijstva na območju MOL se kažejo tudi v primerjavi nekaterih njihovih karakterističnih značilnostih.

Kljub velikim spremembam v številu in velikostni strukturi kmetij v obdobju 1991 do 2000, smo tudi v zadnjih šestih letih priče nadaljevanju teh sprememb ne več le v količinskem ampak vse bolj tudi v kvalitetnem smislu. Vrsta evidentiranih sprememb predvsem na področju usmeritve kmetovanja in socioekonomske sestave kmetij je izrazito pozitivnih, nekatere poteze pa nakazujejo tudi negativne trende. Slednji so predvsem prisotni v vzhodnem, hribovitem delu občine, kjer je ekstenzifikacija rabe zemljišč napredovala do te stopnje, da je ponekod že mogoče identificirati obsežnejša območja zaraščanja. 
Preglednica 6: Stanje in trendi v kmetijstvu na območju $M O L$

Table 6: The present situation and trends in agriculture of Municipality of Ljubljana

\begin{tabular}{|l|c|c|}
\hline Kazalci stanja in razvoja kmetijske dejavnosti & $\begin{array}{c}\text { Stanje popisa } \\
\text { kmetijstva leta 2000 }\end{array}$ & $\begin{array}{c}\text { Rezultati raziskave- } \\
\text { vzorčni popis 2006 }\end{array}$ \\
\hline Število obravnavanih kmetij & 924 & 189 \\
\hline Usmeritev kmetijstva - mešana proizvodnja & $50 \%$ & $35 \%$ \\
\hline Usmeritev kmetijstva v živinorejo & $42 \%$ & $42 \%$ \\
\hline Specializacija v kmetijstvu & $50 \%$ & $60-65 \%$ \\
\hline Delež tržno naravnanih kmetij & $42 \%$ & $78 \%$ \\
\hline Delež gospodarjev starih nad 65 let & - & $30 \%$ \\
\hline Zagotovljeno nasledstvo na kmetiji & $27 \%$ & $43 \% *$ \\
\hline Število prebivalcev na kmetijah & 3412 & 816 \\
\hline Povprečna velikost kmetije (po številu članov) & 3,7 & 4,3 \\
\hline Povprečna velikost kmetije & 6,4 ha & 14,8 ha $(19,8$ ha)** \\
\hline Delež kmetij z več kot 5 ha KZU & $43,4 \%$ & $73 \% * *$ \\
\hline
\end{tabular}

*Tolikšen odstotek anketirancev je navedlo, da kmetija ima potencialnega naslednika.

** Upoštevana vsa kmetijska zemljišča v obdelavi, tako lastna kot najeta.

Vir: Lampičs sodelavci, 2007: Analiza in funkcijsko vrednotenje..., Podatki popisa kmetijstva 2000, povzeto po Strateških usmeritvah razvoja podeželja...2007-2013.

Po ocenah anketiranih kmetov bodo procesi v prihodnjih letih na območju MOLa šli predvsem v smeri širjenja stanovanjskih območij (deloma tudi območij za trgovino, obrt in industrijo), na drugi strani pa se bo hitro povečeval tudi obseg območij zaraščenih z gozdom. Po značilnih pridelovalnih območjih se predstave kmetov o bodoči rabi prostora razlikujejo, na ravninskem območju pa naj bi se raba tal spreminjala v prid povečanemu obsegu stanovanjskih in drugih pozidanih območij, v hribovitem vzhodnem delu občine gredo procesi spreminjanja rabe tal predvsem v smeri zaraščanja, povečal se bo tudi obseg območij počitniških hišic, na barjanskem območju pa na eni strani prevladujejo procesi zaraščanja, na drugi pa povečan obseg stanovanjskih območij. Pomembno mesto v bodoči predstavi kmetov tega območja ima tudi zavarovano območje kot vizija razvoja Barja.

Med splošne okoljske probleme v MOL kmetje uvrščajo predvsem tiste povezane $\mathrm{s}$ prometom (gneča, težka dostopnost, hrup), ki je najbolj moteč na barjanskem in ravninskem območju, neustrezno urejena kanalizacija, neurejena odlagališča odpadkov, škoda in nevšečnosti, ki jo povzročajo rekreativci in sprehajalci, ter t.i. drugi problemi (škoda, ki jo povzroča divjad, poplave, težave z vrtičkarji). Izstopajoči specifični okoljski problemi po območjih so neurejena kanalizacija in poplavljanje na barjanskem območju, težave z divjadjo in slabša oskrba $\mathrm{z}$ vodo $\mathrm{v}$ hribovitem predelu ter motnje zaradi rekreativcev, sprehajalcev $\mathrm{s}$ psi in vrtičkarjev na ravninskem območju. Vloga nekaterih okoljskih problemov je za kmete in kmetijsko pridelavo še posebej pomembna, saj jih ostalo prebivalstvo sploh ne pozna in še manj občuti. To so predvsem težave z divjadjo, rekreativci, sprehajalci in vrtičkarji, težja dostopnost zaradi zgoščenega prometa (dostopnost do obdelovalnih zemljišč). 
Glede okoljskih vplivov živinoreje so razmere na nivoju občine ugodne, saj je povprečna živinorejska gostota tik pod $1 \mathrm{GVŽ/ha} \mathrm{obdelovalnih} \mathrm{površin.} \mathrm{Še} \mathrm{najmanj} \mathrm{ugodne} \mathrm{razmere} \mathrm{z}$ vidka živinorejske gostote so na ravninskem območju. $35 \%$ anketiranih kmetov v MOL ne uporablja mineralnih gnojil. Delež kmetov z večjo hektarsko porabo mineralnih gnojil je nasploh največji na ravninskem območju, kjer je tudi intenzivnost kemtovanja največja, hkrati pa okolje najbolj občutljivo.

Sintezen prikaz kmetijskega obremenjevanja okolja s pomočjo energetska intenzivnost kmetijstva ob upoštevanju vseh vnosov je pokazal ugodno stanje, saj znaša znaša $27 \mathrm{GJ} / \mathrm{ha}$ in je glede na raziskave pred leti drugod po Sloveniji razmeroma ugodno. Obseg in struktura agrarnih vnosov na celotnem območju MOL in po posameznih pridelovalnih območjih so po aktualnih podatkih $\mathrm{z}$ vidika varovanja vodnih virov primerni.

\section{Viri in literatura}

Brečko Grubar, V., Kušar, S., Plut, D. 2000: Regionalna vloga in pokrajinska obremenjenost talne vode Ljubljanskega polja, Ljubljana-geografija mesta, LGD, Založba ZRC, Ljubljana.

Brečko, V. 1998: Pokrajinska občutljivost območij podtalnic v Sloveniji z vidika kmetijstva, Kmetijstvo in okolje (zbornik), Ljubljana.

Cunder, T., 2000: Sedanje stanje in razvojne možnosti kmetijstva. Ljubljana. Geografija mesta. LGD. Ljubljana.

Čergan, Z. 2003: Kmetovanje na vodovarstvenih območjih. Tehnološki list 88/2003. Ljubljana.

Čergan, Z., Dolničar, P., Sušin, J., Verbič, Janez, Verbič, J., Ugrinović, K., Zemljič, A., Maslo, G., 2003: Usmerjanje kmetijstva na vodovarstvenih območjih MOL. Kmetijski inštitut Slovenije. Ljubljana.

Dolgoročni plan občin in mesta Ljubljane za obdobje 1986-2000. 1985, Izvršni sveti skupščin občin in mesta Ljubljane, Ljubljana.

Kladnik, D., Rejec Brancelj, I, 2000: Prostorski, okoljski, socialni in gospodarski učinki intenzivnega kmetovanja $v$ rastlinjakih. Ljubljana. Inštitut za geografijo.

Kladnik, D., 2000. Uveljavljanje intenzivnega pridelovanja $\mathrm{v}$ rastlinjakih. V: Ljubljana - geografija mesta. Ljubljana.

Kladnik, D., 2002: Pomen in perspektive zasebnega kmetijstva znotraj strnjeno pozidanih delov Ljubljane. Inštitut za geografijo. Ljubljana.

Kladnik, D. s sodelavci, 2005: Podtalnica Ljubljanskega polja. Geografija Slovenije 10. Ljubljana.

Kladnik, D., Sajko, I., Smrekar, A., 2002: Kmetijstvo na vodovarstvenih območjih s poudarkom na popisu gnojišč in gnojnih jam. Geografski inštitut Antona Melika, SAZU. Ljubljana.

Klemenčič, M. M., Lampič, B., Perpar, A., Potočnik Slavič, I., Slabe, A., 2005: Strukturni problemi in razvojni izzivi slovenskega podeželja v evropski razsežnosti. CRP. Končno poročilo. UL, Filozofska fakulteta, UL, Biotehniška fakulteta, Inštitut za trajnostni razvoj. Ljubljana. 
Kovačič M., Maslo G., Perpar A., Udovč A., 2003: Strateške usmeritve razvoja kmetijstva, gozdarstva in dopolnilnih dejavnosti na območju Mestne občine Ljubljana. Inštitut za agrarno ekonomiko, MOL. Ljubljana.

Lampič, B. 2000: Izbrani razvojni in okoljevarstveni problemi slovenskega podeželja z vidika sonaravnega razvoja. Pokrajinsko ranljiva območja v Sloveniji, Geographica Slovenica, 33/1. Ljubljana.

Lampič, B., 2000: Ocena ranljivosti prsti in vegetacije. Geografija in njene aplikativne možnosti. Dela 18. Ljubljana.

Lampič, B., 2002: Agrarno obremenjevanje okolja na Slovenskem v energetski osvetlitvi (na izbranih primerih). Doktorska disertacija. Univerza v Ljubljani. Filozofska fakulteta. Oddelek za geografijo. Ljubljana.

Lampič, B., 2005: Kmetijstvo kot priložnost sonaravnega razvoja podeželja v Sloveniji. Dela 23. Ljubljana.

Lampič, B., Cigale, D., Plut, D., Potočnik Slavič, I., Repe, B., 2007: Analiza in funkcijsko vrednotenje kmetijstva z vidika vplivov na naravne vire na območju celotne Mestne občine Ljubljana. Končno poročilo. Oddelek za geografijo, Filozofska fakulteta, Univerza v Ljubljani. Ljubljana.

Medmrežje 1; 12. 12. 2005: http://rkg.gov.si/GERK/

Medmrežje 2; 6. 5. 2007: http://kazalci.arso.gov.si/kazalci/index_html

Okolje v mestni občini Ljubljana, 2004. Poročilo o stanju okolja. Zavod za varstvo okolja, Ljubljana.

Petrovič, M. 2007: Učinki intenzivnega kmetovanja v rastlinjakih na primeru Slovenije in Nizozemske. Diplomsko delo. Filozofska fakulteta, Oddelek za geografijo. Ljubljana.

Prostorski plan Mestne občine Ljubljana - prostorska zasnova, 2002, MOL - Oddelek za urbanizem, Ljubljana.

Radinja, D. 1991: Kmetijsko obremenjevanja okolja na Slovenskem v energetski osvetlitvi (tipkopis). Oddelek za geografijo, Filozofska fakulteta, Univerza v Ljubljani. Ljubljana.

Radinja, D. 1996: Obremenjevanje pokrajinskega okolja v Sloveniji zaradi energijske intenzivnosti »družbenega« kmetijstva. Geografski vestnik 68. Ljubljana.

Regionalni razvojni program Ljubljanske urbane regije za obdobje 2002-2006, Analiza posnetek stanja. RRA LUR, Ljubljana. 2002.

Rejec Brancelj, I., 2000: Okoljski učinki intenzivnega kmetovanja v rastlinjakih. Ljubljana - geografija mesta. Ljubljana.

Smrekar, A., s sodelavci, 2003: Popis vodnjakov in vrtin na območju varovanja vodnih virov Mestne občine Ljubljana. Geografski inštitut Antona Melika. ZRC SAZU. Ljubljana.

Strateške usmeritve razvoja podeželja na območju mestne občine Ljubljana v obdobju 20072013. MOP, Oddelek za gospodarske dejavnosti in turizem, Kmetijski inštitut Slovenije, Kmetijsko gozdarska zbornica Slovenije, Zavod za gozdove Slovenije, Zavod za razvoj podeželja. Ljubljana. 2007.

Sušin, J., s sodelavci, 2002: Monitoring rastlinskih hranil v tleh na vodovarstvenem območju MOL, Poročilo za leto 2001. Kmetijski inštitut Slovenije. Ljubljana.

Sušin, J., 2002: Gnojenje na vodovarstvenih območjih. Tehnološki list 85/2002. Ljubljana. 
Udovč, A., Kovačič, M., Kramarič, F., 2006: Socio-ekonomski tipi kmetij po podatkih popisa kmetijskih gospodarstev v letu 2000. Slovenija v EU - Izzivi za kmetijstvo, živilstvo in podeželje. DAES. Moravske Toplice.

Uredba o vodovarstvenem območju za vodno telo vodonosnika Ljubljanskega polja. Uradni list Republike Slovenije 120/2004. Ljubljana.

Usmerjanje kmetijstva na vodovarstvenih območjih Mestne občine Ljubljana, zaključno poročilo, 2003. Kmetijski inštitut Slovenije. Ljubljana.

Zasnova prostorskega razvoja. Prostorski plan MOL. Gradivo za razpravo. Mestna občina Ljubljana. 2001.

\section{THE ENVIRONMENTAL AND DEVELOPMENTAL ROLE OF AGRICULTURE IN MUNICIPALITY OF LJUBLJANA}

\section{Summary}

Ljubljana and the greater area of the whole Municipality of Ljubljana have been undergoing quick and extensive changes that are mainly the result of the economic role of the capital. Agriculture as a non-competitive segment of the economy has assumed a rather specific position in this area: trapped amid self-assertive and fast developing economic activities, it still occupies an important part of increasingly valued »unoccupied «, i.e. non built-up areas. The latest comprehensive field study which focused on the farms still operating in the municipality as a whole (Lampič et. al., 2007) tackled, on the one hand, the evaluation of agriculture as a potential burdening factor for the environment, and at the same time assessed the present role of the farms and agriculture perspectives in the municipality following an exhaustive analysis of demographic and socio-economic features of the existing farms. The presented results which are derived from a situation analysis of approximately $30 \%$ of the active Ljubljana farms (189 farms) are a relatively good reflection of agriculture situation and trends in the municipality.

There has been a growing tendency (compared to the situation in Slovenia) towards orientation and specialization of otherwise scant farms in Municipality of Ljubljana (MOL), and notably towards their presence in the market (almost $80 \%$ of them already). A large part of the existing farms involved in the survey plans to keep the present range and method of production (42\%). Almost $25 \%$ of them await new perspectives in the development of their farms. In the following years, a good $30 \%$ of the farms intend to give up the practice of farming, claiming that there is no real future for them in agriculture or that they are not able to carry on with this activity because of the old age and sparse workforce. The highest level of farms without a perspective was identified in the marshland (50\%) and the lowest in flat areas $(29 \%)$.

With reference to spatial development, farmers estimate that future processes will develop primarily towards the spreading of housing areas ( $42 \%$ responses) and rapid expansion of areas overgrown with forest (25\% responses). The land use in flat areas is supposed to change in favour of a higher percentage of housing and other built-up areas. In the hilly 
eastern part of municipality, the processes of land use changes include mainly overgrowing and the spreading of areas intended for second homes. According to the opinion of farmers, the marshlands have been largely subjected to the processes of overgrowing, while some areas experience an uncontrolled growth and an increased expansion of housing areas.

When asked about common environmental problems, farmers generally indicate traffic-related problems (density, difficult accessibility, noise) that are particularly disturbing in moor and flat lands. Specific environmental problems that are critical in individual areas include sewage systems and flooding in the moor lands, problems with deer and inadequate supply of water in the hilly areas, and disturbances in the fields of flat lands because of dog walkers and allotment holders. The role of some environmental problems is specifically important to farmers, as it is neither known to nor felt by the rest of the population. These include mostly problems with deer, recreationists, walkers, allotment holders and difficult access to farming areas due to traffic density.

With reference to environmental effects of livestock breeding, the situation at the municipality level has been improving. The average livestock density is namely just below $1 \mathrm{LU} /$ ha (livestock unit per hectar) of the farmland. The synthesized review of agriculture burdening of the environment based on energetic intensity of agriculture reflects an appropriate situation with $27 \mathrm{GJ}$ per hectare. Compared to past surveys in other parts of Slovenia, it is relatively favourable. As expected, the energy consumption is the highest in flat lands (31 GJ/ha), and yet it is still relatively low and environment friendly due to water protection areas and prescribed restrictions. The environmental inputs in agriculture have been decreasing. A major problem from the perspective of preserving natural resources is the improper use of land; the overgrowing of hilly and moor areas, as well as pressures through other types of activity in flat and moor lands.

It can be concluded that there have been some gradual positive changes identified towards reducing the intensity of agriculture influence on the environment, notably with reference to agriculture pressures. A relatively solid structure of farms in the municipality is also worth emphasizing. However, the issue of overgrowing, notably in the hilly and partially in marsh hinterland areas of municipality, and extensive, often poorly planned changes in land use, are still a matter of growing concern. The capital will not be able to avoid these processes, but it can plan and direct them with regard to an indisputable fact that space as a non-renewable natural source is undoubtedly most at risk. 